\title{
Silence as an element of care: a meta-ethnographic review of professional caregivers' experience in clinical and pastoral settings
}

\begin{abstract}
Background: In interactions between professional caregivers, patients and family members at the end of life, silence often becomes more prevalent. Silence is acknowledged as integral to interpersonal communication and compassionate care but is also noted as a complex and ambiguous phenomenon. This review seeks interdisciplinary experience to deepen understanding of qualities of silence as an element of care.
\end{abstract}

Aim: To search for published papers which describe professional caregivers' experience of silence as an element of care, in palliative and other clinical, spiritual and pastoral care settings and to synthesise their findings.

Design: Meta-ethnography: employing a systematic search strategy and lines-ofargument synthesis.

Data sources: PsycINFO and seven other cross-disciplinary databases, supplemented by hand-search, review of reference lists and citation tracking. No date range was 
imposed. Inclusion criteria focused on reported experience of silence in professional caregiving. Selected papers $(n=18)$ were appraised; none were rejected on grounds of quality.

Results: International, interdisciplinary research and opinion endorses the value of silence in clinical care. As a multi-functional element of interpersonal relationships, silence operates in partnership with speech to support therapeutic communication. As a caregiving practice, silence is perceived as particularly relevant in spiritual and existential dimensions of care when words may fail.

Conclusions: Experience of silence as an element of care was found in palliative and spiritual care, psychotherapy and counselling supporting existing recognition of the value of silence as a skill and practice. Because silence can present challenges for caregivers, greater understanding may offer benefits for clinical practice.

\section{Keywords}

Caregivers, interdisciplinary communication, palliative care, pastoral care, spirituality, silence 


\section{What is already known about the topic?}

- Silence is used as an interpersonal communication tool and is an integral element of compassionate care.

- Silence may be used to further therapeutic aims and therapeutic relationships.

- As a spiritual practice, silence support personal wellbeing.

\section{What this paper adds}

- This paper provides a novel synthesis of professional caregivers' experience of silence in interdisciplinary settings.

- Findings suggest that silence has the potential to support therapeutic communication especially in spiritual and existential domains of care.

- The line of argument adds an interpretation of silence that is relevant to palliative settings.

\section{Implications for research, education and practice}

- This review supports the case for further research into silence as an element of palliative spiritual care

- Findings highlight the need for training in the use of silence, and opportunities to practice silence, for professional caregivers. 
- The study concludes that greater understanding of silence, as an element of care, may support professional caregiving practice in palliative care. 


\section{Introduction}

Towards the end of life, silence seems to take increasing prominence in interactions between professional caregivers and patients and their family members. In westernised health and palliative care settings, silence is recommended to clinicians as an inter-personal communication tool ${ }^{1,2,3}$ and an integral element of compassionate care $^{4,5,6}$. An article by Back et al. ${ }^{6}$, included in this review, describes experience in the United States of America; it identifies compassionate silence, derived from contemplative practice, as a typology of silence in patient-clinician encounters. Silence is recognised as a complex phenomenon, more than simply an absence of speech ${ }^{7}$ but also more ambiguous than speech. ${ }^{8}$ Back et al. ${ }^{6}$ note that "while there are silences that feel awkward, indifferent or even hostile, there are also silence that feel comforting, affirming and safe" (p. 1113).

The value of silence is recognised in many world religions ${ }^{9}$ and there is a growing body of evidence for silent meditative practices such as mindfulness ${ }^{10}$ for personal spiritual wellbeing but no empirical research has been found that explores silence as an element of end-of-life spiritual care. Greater understanding of the phenomenon, from the perspective of professional caregivers, has the potential to benefit practice. 
For the purpose of this review, 'silence as an element of care' is defined as silence which occurs, or is used, in interactions between professional caregivers, including health professionals, social workers and chaplains, and their patients or clients with the intention of supporting the wellbeing of that person. This serves to distinguish it from unhelpful silences such as the conspiracy of silence, noted by Twycross ${ }^{11}$ as preventing people from sharing their fears and anxieties.

The objective of the review was to search for published papers which describe professional caregivers' experience of silence as an element of care, in palliative and other clinical, spiritual and pastoral care settings and to synthesise their findings with the aim of gaining a deeper understanding of the phenomenon. Clinical care is understood as face-to-face medical or nursing care for patients or clients, spiritual care is a domain of healthcare which responds to the needs of the human spirit. ${ }^{12}$ Rumbold, researching palliative care in Australia, explains that whilst spiritual care can be a dimension of any discipline, pastoral care "is a person centred approach to care that complements the care offered by others while paying particular attention to spiritual care" ${ }^{\prime 13}$ The review question asked: How do people in professional caregiving roles describe their experience of silence, as an element of care, in interactions with patients or clients? 


\section{Method}

A meta-ethnographic approach was adopted, following Noblit and Hare, ${ }^{14}$ to produce an interpretation of existing understanding of silence as an element of care.

Considered the pre-eminent approach in qualitative synthesis, ${ }^{15}$ meta-ethnography offers an interpretive method for synthesising disparate data from individual case studies. ${ }^{16}$ This suited the heterogeneous, cross-disciplinary and self-reflective nature of the material in this review, drawn from different psychological disciplines, palliative care, nursing and pastoral care and presented as reported research, personal reflections and clinical cases that are neither suited to direct comparison nor report significant disagreement ${ }^{17}$.

Where disparate papers report findings from their own perspective, Noblit and Hare ${ }^{14}$ propose a lines-of-argument synthesis. It is a two-step process which first compares themes and concepts across studies, clustering similar findings and noting differences and then, draws together the main arguments of each paper to frame a new line-ofargument. The aim is 'to discover a "whole" among a set of parts' (p.63).

\section{Information sources and search strategy}

A systematic search process was undertaken to retrieve relevant work across disciplines that include an interpersonal approach to care. The search was undertaken 
in March 2015. The search strategy used in PsycINFO is shown in Table 1. It was adapted for seven other cross-disciplinary databases: Academic Search Complete, AMED, CINAHL, Index to Theses, International Bibliography of the Social Sciences, Medline and ProQuest Digital Dissertations. No date range was applied; some databases applied a default range.

Table 1. Search strategy for PsycINFO database (Search date: $15^{\text {th }}$ March 2015)

\begin{tabular}{|ll|}
\hline Main search areas & Search terms \\
\hline Silence & silence [free text] OR silence [MeSH term] \\
& AND \\
Discipline & therapeutic processes [MeSH term] OR therapeutic environment [MeSH \\
& term] OR psychotherapeutic processes [MeSH term] OR \\
& psychotherapeutic counselling OR palliative care [MeSH term] OR \\
& meditation [MeSH term] OR spirituality [MeSH term] OR pastoral \\
& counselling [MeSH term] OR therap* [title /abstract] OR counsel* \\
& [title/abstract] \\
& AND \\
& patients [MeSH term] OR geriatric patients [MeSH term] OR hospitalised \\
patients [MeSH term] OR medical patients [MeSH term]OR outpatients & \\
& [MeSH term] OR psychiatric patients [MeSH term] OR surgical patients \\
& [MeSH term] OR terminally ill patients [MeSH term] OR clients [MeSH \\
& term] OR patient* [title /abstract] OR client [title /abstract] OR therap \\
& [title /abstract] \\
& AND \\
& English \\
Language &
\end{tabular}

Indexes of the following discipline-specific journals were searched by hand for additional material relating to spiritual and pastoral care: Journal of Health Care Chaplaincy (US), Journal of Health Care Chaplaincy (UK), Scottish Journal of Healthcare Chaplaincy, Journal of Religion and Health, Journal for the Study of Spirituality, 
Practical Theology. The search was supplemented by citation-tracking and review of reference lists of included articles.

\section{Study selection}

Records which address the experience of silence as an element of care in professional caregiving interactions were retained according to inclusion and exclusion criteria show in Table 2. After initial screening, retained records in each service were downloaded to an Excel file for deduplication. Eligible articles were assessed by title and abstract; where they met the inclusion criteria, full text was reviewed. This process was undertaken by the first author. It was discussed with co-authors at each stage to ensure that selection decisions were appropriate and consistent. 
Table 2. Inclusion and exclusion criteria

\begin{tabular}{|c|c|c|}
\hline & Inclusion & Exclusion \\
\hline 1. & English language texts & \\
\hline 2. & $\begin{array}{l}\text { Empirical research and articles published in peer } \\
\text { reviewed journals }\end{array}$ & Book reviews \\
\hline 3. & Focus on silence & \\
\hline 4. & $\begin{array}{l}\text { Silence in professional caregiving interactions with } \\
\text { patient, client or family member }\end{array}$ & $\begin{array}{l}\text { Group therapy } \\
\text { Non-caregiving disciplines } \\
\text { Inter-professional communication } \\
\text { Non-professional caregiving e.g. family } \\
\text { or informal carers }\end{array}$ \\
\hline 5. & $\begin{array}{l}\text { Focus on silence as an element of care } \\
\text { including clinical consultation or therapy }\end{array}$ & $\begin{array}{l}\text { Silence that is not caregiving: } \\
\text { patient/ client silence } \\
\text { taboo/ stigma, that which is 'not } \\
\text { discussed' } \\
\text { 'conspiracy of silence' } \\
\text { use of silence as power or control } \\
\text { Self-care } \\
\text { Silence as a part of individual spiritual } \\
\text { practice }\end{array}$ \\
\hline 6. & $\begin{array}{l}\text { Reports primary experience of silence from the } \\
\text { perspective of the professional caregiver }\end{array}$ & $\begin{array}{l}\text { Does not include primary experience } \\
\text { of silence }\end{array}$ \\
\hline
\end{tabular}

\section{Data collection process}

In a manual data extraction process, a 14 point data extraction sheet was devised to capture information about the article or study including focus, conceptualisation of silence, main findings and a descriptive summary. This informed the final selection of articles for inclusion. 


\section{Quality}

Reports of empirical research were appraised for quality and risk of bias using a critical appraisal tool, developed by Hawker et al. ${ }^{16}$ for reviews of diverse studies and heterogeneous data. Studies were scored, between 10 and 40 points, on each of nine criteria resulting in a maximum possible score of 360 points. Other articles were assessed using an adaptation of the tool. Selected articles, and especially two low scoring articles, were discussed with the co-authors. No papers were excluded on grounds of quality because they all contributed primary experience of the phenomenon to the synthesis.

\section{Results}

Thirty-nine papers were retained for full text review; of these 16 were identified as meeting the inclusion criteria. Citation tracking identified two further relevant papers thus a total of 18 studies and articles were included the meta-ethnographic synthesis. Figure 1 describes the flow of the literature search process and Table 3 summarises the final selection of studies and articles. 


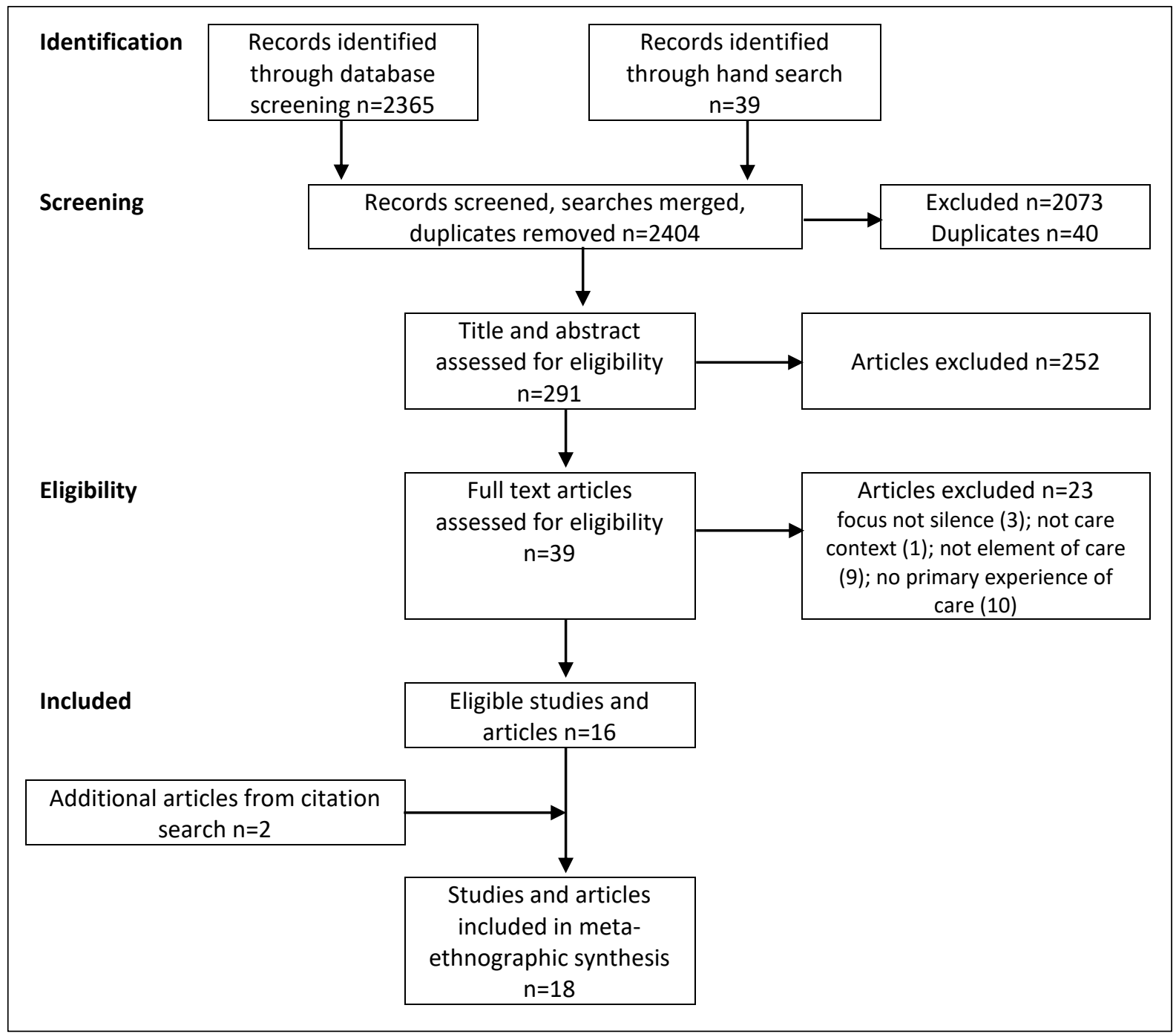

Figure 1. Flow diagram to show literature search process

Source: Modified PRISMA flow chart as described by Moher et al. (2009) ${ }^{18}$ 
Table 3. Studies and articles included in review

\section{Empirical research}

\begin{tabular}{|c|c|c|c|c|}
\hline $\begin{array}{l}\text { Author/date/ } \\
\text { country where study } \\
\text { was conducted }\end{array}$ & Discipline/ context & $\begin{array}{l}\text { Methodology/ } \\
\text { design/ sample }\end{array}$ & $\begin{array}{l}\text { Quality assessment } \\
\text { (Score out of maximum } \\
360 \text { points) }\end{array}$ & Focus of study \\
\hline $\begin{array}{l}\text { Barber, T. } \\
2009 \\
\text { UK }\end{array}$ & $\begin{array}{l}\text { Counselling } \\
\text { Psychotherapy }\end{array}$ & $\begin{array}{l}\text { Phenomenological } \\
\text { Semi-structured interviews; data-driven thematic } \\
\text { analysis } \\
7 \text { newly qualified counsellors }\end{array}$ & 350 & Therapists' experience of silence \\
\hline $\begin{array}{l}\text { Hill, C. et al. } \\
2003 \\
\text { USA }\end{array}$ & Psychotherapy & $\begin{array}{l}\text { Mailed survey; } 5 \text { point Likert scales } \\
81 \text { therapists }\end{array}$ & 320 & Therapists' use of silence in therapy \\
\hline $\begin{array}{l}\text { Ladany, N. et al. } \\
2004 \\
\text { USA }\end{array}$ & Psychotherapy & $\begin{array}{l}\text { Consensual qualitative approach } \\
12 \text { therapists }\end{array}$ & 300 & Therapists' use of silence in therapy \\
\hline $\begin{array}{l}\text { Tornøe, K. et al. } \\
2014 \\
\text { Norway }\end{array}$ & Hospice nursing & $\begin{array}{l}\text { Phenomenological hermeneutical (after Ricoeur) } \\
\text { Narrative approach to interviews and analysis } \\
8 \text { nurses }\end{array}$ & 310 & $\begin{array}{l}\text { Being with dying people; alleviating } \\
\text { spiritual and existential suffering }\end{array}$ \\
\hline
\end{tabular}




\section{Articles and commentary}

\begin{tabular}{|c|c|c|c|c|}
\hline $\begin{array}{l}\text { Author/ date/ } \\
\text { country of } \\
\text { publication }\end{array}$ & Discipline/ context & $\begin{array}{l}\text { Reported experience } \\
\text { (numbers of reported cases or clinical vignettes) }\end{array}$ & $\begin{array}{l}\text { Theory/philosophical } \\
\text { perspective }\end{array}$ & Focus \\
\hline $\begin{array}{l}\text { Back, A. et al. } \\
2009 \\
\text { USA }\end{array}$ & $\begin{array}{l}\text { Palliative care } \\
\text { Communication }\end{array}$ & One & $\begin{array}{l}\text { Mindfulness } \\
\text { Christian/ Buddhist } \\
\text { contemplative traditions }\end{array}$ & Compassionate silence: a new typology \\
\hline $\begin{array}{l}\text { Bravesmith, A. } \\
2012 \\
\text { UK }\end{array}$ & $\begin{array}{l}\text { Psychoanalysis } \\
\text { Psychoanalytic } \\
\text { dialogue }\end{array}$ & Two & Jungian approach & $\begin{array}{l}\text { Speech and silence as a partnership for } \\
\text { creation of meaning }\end{array}$ \\
\hline $\begin{array}{l}\text { Bunkers, S. S. } \\
2013 \\
\text { USA }\end{array}$ & Nursing & One & & Silence as bearing witness to life story \\
\hline $\begin{array}{l}\text { Capretto, P. } \\
2014 \\
\text { USA }\end{array}$ & $\begin{array}{l}\text { Pastoral care/hospice } \\
\text { chaplaincy } \\
\text { Grief and loss }\end{array}$ & Two & $\begin{array}{l}\text { Attachment/ mourning } \\
\text { theory. Freudian analysis } \\
\text { and Christian tradition }\end{array}$ & $\begin{array}{l}\text { Silence as a therapeutic tool in } \\
\text { bereavement care }\end{array}$ \\
\hline $\begin{array}{l}\text { Denham-Vaughan, J., } \\
\text { Edmond, V. } \\
2010 \\
\text { New Zealand }\end{array}$ & $\begin{array}{l}\text { Gestalt } \\
\text { psychotherapy }\end{array}$ & Two & $\begin{array}{l}\text { Theory of presence: } \\
\text { Buber, Sartre }\end{array}$ & $\begin{array}{l}\text { Hypothesis: Attending to silence is a } \\
\text { figure-ground reversal resulting in } \\
\text { interconnectedness }\end{array}$ \\
\hline
\end{tabular}




$\begin{array}{lll}\begin{array}{l}\text { Harris, A. } \\ \text { UK }\end{array} & \begin{array}{l}\text { Person-centred } \\ \text { therapy }\end{array} & \text { One } \\ \text { Hill, M. } & & \\ 2004 & \text { Psychoanalysis } & \text { Two (one patient) } \\ \text { USA } & & \\ \text { Himelstein, B. et al. } & \begin{array}{l}\text { Paediatric palliative } \\ \text { care }\end{array} & \text { One } \\ \text { USA } & \begin{array}{l}\text { Consultation with } \\ \text { patient's mother }\end{array} & \\ & \begin{array}{l}\text { Nursing } \\ \text { Home healthcare }\end{array} & \\ \text { King, K. } & & \\ \text { USA } & & \text { Two } \\ \text { Moriichi, S. } & \begin{array}{l}\text { Pastoral care } \\ \text { Nursing home }\end{array} & \text { Two } \\ \text { USA } & & \\ & & \end{array}$

Rogers

Freud, Lacan: empty and full speech.

Buddhism

Communication: Saville

Troike

Clinical Pastoral

Education (CPE)

Eastern culture

Christianity
The power of silence in the therapeutic relationship.

Compares silence in psychoanalysis with Buddhist meditation. Use of silence as practice in therapy.

Practicing the art of silent presence

Nurses' use of silence

Proposes a counter-cultural adjustment

to the perception of silence 


\begin{tabular}{|c|c|c|c|c|}
\hline $\begin{array}{l}\text { Rajski, P. } \\
2003 \\
\text { Canada }\end{array}$ & $\begin{array}{l}\text { Psychology } \\
\text { Therapy }\end{array}$ & One & $\begin{array}{l}\text { Contemplative Christian } \\
\text { spirituality }\end{array}$ & $\begin{array}{l}\text { Contemplative prayer informed silence } \\
\text { in therapy }\end{array}$ \\
\hline $\begin{array}{l}\text { Sabbadini, A. } \\
2004 \\
\text { UK }\end{array}$ & Psychoanalysis & Two & & $\begin{array}{l}\text { The function of silence in the } \\
\text { psychoanalytic encounter }\end{array}$ \\
\hline $\begin{array}{l}\text { Savett, L. } \\
2011 \\
\text { USA }\end{array}$ & Medical education & One & & $\begin{array}{l}\text { The importance and practice of } \\
\text { deliberate silence for health care } \\
\text { professionals }\end{array}$ \\
\hline $\begin{array}{l}\text { Wilmer, H. } \\
1995 \\
\text { USA }\end{array}$ & Psychoanalysis & Four & Jungian approach & $\begin{array}{l}\text { Deep communication when analyst and } \\
\text { analysand are both "listening into" the } \\
\text { silence }\end{array}$ \\
\hline
\end{tabular}




\section{Location and methodology}

Articles are drawn from the disciplines of palliative care and nursing $(n=6)$, pastoral care $(n=2)$ and psychotherapy and counselling $(n=10)$. With the exception of Barber's MA dissertation ${ }^{19}$, articles were published in peer reviewed journals, primarily in the USA and Canada ( $n=12)$. The majority $(n=16)$ were published after the year 2000 . All selected papers describe experience in western countries; one paper ${ }^{32}$ reports the cross-cultural learning experience of a Japanese author who trained and worked as a chaplain in America.

Four papers report empirical research. Of these, three are located in psychotherapy; ${ }^{19,20,21}$ the studies by Hill et al. ${ }^{20}$ and Ladany et al., ${ }^{21}$ conducted in the USA, are closely linked and explore why therapists' use silence. Barber's research, ${ }^{19}$ in the UK, also draws on the work of Ladany et al, ${ }^{21}$ taking a phenomenological and thematic approach to analyse therapists' experience of silence within the therapeutic setting. In the field of palliative care, Torn øe et al, ${ }^{22}$ adopted a phenomenological approach to explore Norwegian hospice nurses' experience of consoling presence; silence emerges as a result, not the focus, of the research.

The prevailingly qualitative methodologies reflect the nature of inquiry into experience. Aside from the survey, mailed to 81 therapists, ${ }^{20}$ samples were small, 
(range: 7 - 12) consistent with a qualitative research design. Methods are clearly reported; low quality appraisal scores for all four papers were in the category of 'ethics and bias ${ }^{16}$. All report primary experience of participants which is the focus of this review. The other 14 articles provide data for synthesis in the form of reflection on personal experience.

\section{Theory and philosophical underpinning}

No predominant theory emerges but each article draws on scholarship from its own discipline and more generally from the fields of psychology, communication and spiritual traditions. The breadth of influence illustrates the heterogeneity of the selected material.

\section{Data synthesis and interpretation}

Silence is found to be a multi-faceted ${ }^{20}$ and multi-functional phenomenon. ${ }^{23}$ It affords a spectrum of intention and perception, includes extremes of experience and does not lend itself to any definitive interpretation, prescription or significance. ${ }^{21,23}$ As human communication, silence occurs within a context ${ }^{23}$ and a relationship. ${ }^{19,22}$

Used well, silence can lead to therapeutically rich moments..$^{20,24,25}$ Positive experiences of silence are described as comfortable, affirming and safe ${ }^{6,26}$ but silence may also be 
received as awkward, ${ }^{6}$ embarrassing,${ }^{27}$ frustrating or frightening. ${ }^{28}$ Bunkers, ${ }^{29}$ a Professor of Nursing in South Dakota, describes silence as 'a double edged-sword' (p.7), a powerful force for connection or rejection; Barber, ${ }^{19}$ reporting the experience of UK psychotherapists, finds that, either way, it can 'touch the deepest emotion' (p.54). The quality of silence, sought in this review, is described in these contexts as therapeutic silence. ${ }^{6,19,24,30}$

Silence and anxiety Sabbadini ${ }^{23}$ highlights a connection between silence and anxiety. This is borne out in research findings; ${ }^{20,21}$ when anxious, some therapists use more silence, some less. ${ }^{21}$ Anxiety may lead to too many words and too little silence, ${ }^{19,27}$ but too much silence is also been identified as a source of anxiety in both therapy $y^{20,28}$ and healthcare. ${ }^{6,24}$ Bravesmith ${ }^{28}$ describes her aim for an 'optimal pause' (p.26); King ${ }^{24}$ suggests a well-timed silence of ideal length.

The studies and articles fall into three areas of focus: the relationship of silence and speech, the use of silence and the practice of silence. These are drawn from the main arguments interpreted from each paper, summarised in Table 4. 
Table 4. Summary of main arguments of selected papers in three areas of focus

\begin{tabular}{|c|c|c|}
\hline $\begin{array}{l}\text { Focus one: Relationship of } \\
\text { silence and speech }\end{array}$ & Focus two: Use of silence & Focus three: Practice of silence \\
\hline $\begin{array}{l}\text { Bravesmith: }{ }^{28} \text { Silence aids speech } \\
\text { to integrity } \\
\text { Capretto: }^{30} \text { Silence is the } \\
\text { acceptance of the limits of } \\
\text { empathetic language and } \\
\text { differentiation of psychic } \\
\text { differences offering theological } \\
\text { wholeness } \\
\text { Denham Vaughan and Edmond: } \\
\text { Attending to silence is a figure- } \\
\text { ground reversal resulting in } \\
\text { interconnectedness } \\
\text { Harris: }{ }^{31} \text { The dominant discourse } \\
\text { in person centred therapy may } \\
\text { distract therapists from non- } \\
\text { verbal interventions and silence } \\
\text { Sabbadini: }{ }^{23} \text { Silence is } \\
\text { complementary to speech, 'a } \\
\text { container of words' (p.229) }\end{array}$ & $\begin{array}{l}\text { Barber: }{ }^{19} \text { A useful phenomenon } \\
\text { which becomes more } \\
\text { comfortable with experience } \\
\text { Hill et al.: }{ }^{20} \text { Therapists use } \\
\text { silence to enhance the } \\
\text { therapeutic relationship } \\
\text { King: }{ }^{24} \text { Silence is often } \\
\text { uncomfortable but when used } \\
\text { purposefully can aid effective } \\
\text { communication } \\
\text { Ladany et al.: }{ }^{21} \text { Silence is multi- } \\
\text { functional and has multiple } \\
\text { conceptions. It is used for } \\
\text { different interests }\end{array}$ & $\begin{array}{l}\text { Back et al.: }{ }^{6} \text { Compassionate } \\
\text { silence enables a kind of } \\
\text { communication that fosters } \\
\text { healing } \\
\text { Bunkers: }{ }^{29} \text { Silence as bearing } \\
\text { witness to life story } \\
\text { Hill: }{ }^{19} \text { Silence, like meditation, is } \\
\text { a letting go of ego } \\
\text { Himelstein et al.: }{ }^{25} \text { Silent } \\
\text { presence is an empowering but } \\
\text { difficult skill to master } \\
\text { Moriichi: }{ }^{32} \text { A counter cultural } \\
\text { adjustment in the perception of } \\
\text { silence is needed } \\
\text { Rajski: }{ }^{33} \text { Silence is the royal way } \\
\text { to discovering God. Finding the } \\
\text { divine particle in self and client } \\
\text { changes therapy } \\
\text { Savett: }{ }^{34} \text { Silence is necessary for } \\
\text { listening } \\
\text { Tornøe et al.: }{ }^{22} \text { Silence with } \\
\text { another has a powerful } \\
\text { Silence of the other fosters deep } \\
\text { communication }\end{array}$ \\
\hline
\end{tabular}




\section{Focus one. The relationship of silence and speech}

All papers discuss silence in the context of conversation. Authors suggest that, understood and used skilfully, silence presents not as absence of speech, ${ }^{28,30}$ but as an active presence; silence is described by Sabbadini, a psychoanalyst practicing in the UK, as 'a container of words'. ${ }^{23}$ Another UK psychoanalyst, Bravesmith, ${ }^{28}$ invokes Jungian theory to conceptualise the partnership between silence and speech as a union of opposites offering the potential for new and holistic meaning to arise.

In relation to speech, silences are described as pause, a way of listening and attending, and a way of communicating that is beyond words; these are discussed below. Lastly, and relevant to the experiences of anxiety noted above, the question of responsibility for silence in professional-patient interactions is addressed.

Silence as pause is noted in the research of Ladany et al. ${ }^{21}$ as a quality of relationship and presence. In both therapy and nursing care it is recognised that silent pauses allow the conversation to slow down conveying respect ${ }^{18}$ and reverence. ${ }^{29}$ Savett, $^{34} \mathrm{a}$ physician and teacher of medical students in the USA, explains: "if silence is interrupted too soon, one may fracture the narrative and miss important information" (p.170). Bravesmith ${ }^{28}$ suggests that sometimes a story is still in the process of creation; this may need time, space and a listener. Similarly, Savett ${ }^{34}$ and Bunkers, ${ }^{29}$ writing to 
inform the practice of nurses, introduce a concept of waiting for the story to be told to completion.

Savett ${ }^{34}$ states that 'to listen one has to be silent' (p.169). In therapy, Bravesmith ${ }^{28}$ describes a productive silence which allows patients time, through semicommunicative chatter, to gain personal insight and to build the trust necessary for a significant disclosure to be articulated. Bunkers ${ }^{29}$ comments that a silent listener bears witness to life-story and offers space 'for the narrative to unfold' (p.9).

Attending is described as listening, not only to words but also to silences. ${ }^{19,23,35}$ Jungian analyst, Wilmer ${ }^{35}$ from the UK, suggests that deepest communication takes place when analyst and analysand are engaged in the psychoanalytic process of 'listening in' to the silence of the other. Gestalt theory describes this as a figure ground reversal, whereby silence, normally the ground of conversation, becomes the figure or focus. ${ }^{27}$

Denham-Vaughan and Edmond ${ }^{28}$, exploring the value of silence within their shared interest of Gestalt therapy in the UK and New Zealand respectively, assert that 'the deepest level of connection may only be possible in total stillness and silence' (p.16). Their suggestion that words may only serve as interruption is echoed in other papers $27,28,30$ and illustrated by Capretto, ${ }^{30}$ a hospital chaplain, in the USA, working with bereavement. In his example of supporting a woman by the bedside of her dying 
mother, he notes that it was when he 'stopped talking and let the moment be' (p.354), that she was released to find a way forward. Capretto claims that therapeutic silence accomplishes something that cannot be fully actualised in speech; this includes both respect and non-abandonment. Tornøe et al. ${ }^{22}$ report that palliative care nurses in Norway recognise a similar quality of silence in care of the dying; they conclude that there comes a time when it is too late for words, when words lose all meaning.

Acknowledging the ambiguity of silence, Back et al. ${ }^{6}$ emphasise that the effects of silence in the clinical encounter are largely the responsibility of the clinician. This is also recognised in therapy ${ }^{19,23,31}$ and nursing. ${ }^{24,34}$ Authors note that where the intention of the caregiver is for the wellbeing of the patient, ${ }^{20}$ every silence presents a decision; wise decisions not to speak are described as intentional, deliberate, ${ }^{34}$ or purposeful. ${ }^{24}$

\section{Focus two. The use of silence}

All papers refer to use of silence. Ladany et $\mathrm{al}^{21}$ find a range of client focused reasons why therapists use silence in therapy; some convey a quality of themselves, such as understanding, empathy, respect, others are supportive in quality, including holding, facilitating reflection or giving the client permission to be themselves. A third category attends to the therapeutic space, honouring what has been said and providing the 
conditions that facilitate therapeutic work. They conclude that 'no specific recommendations can be made in terms of when to use silence' (p.7) amplified by Hill et al., ${ }^{20}$ 'Clinically, it does not make sense that more or less silence would necessarily be good; rather it makes sense that silence could have many different impacts depending on timing and client need' (p.514). It is generally agreed that a strong therapeutic alliance is a pre-requisite for the use of silence. ${ }^{20,21,23}$

There is acknowledgment that use of silence requires training and practice but Hill et al. ${ }^{20}$ and Ladany et al. ${ }^{21}$ find that there is little formal training in the use of silence in psychotherapeutic practice. Therapists attribute growing confidence largely to their own clinical and supervision experience. ${ }^{19}$ Hill et al. ${ }^{20}$ conclude, 'It could be that graduate programmes are not doing enough to teach therapists how to use silence or it could be that silence is an advanced skill that can only be learned through clinical experience' (p.521). In pastoral care, Moriichi ${ }^{32}$ and Capretto ${ }^{30}$ note that, training focuses more on what to say. Across disciplines it is agreed that developing confidence and competence to use silence effectively takes practice. ${ }^{6,24,32,34,35}$ In addition several papers support the interpretation of Barber ${ }^{19}$ that: 'It is not enough for the therapist simply to 'use' silence with a client. There appears to be a need for it to be experienced by both' (p.53 original italics). 
This is demonstrated in paediatric palliative care practice in the USA by Himelstein et al. ${ }^{25}$ who describe the demanding experience of staying present in silence with the anguish of a mother to allow her time to engage with the reality of her child's dying. Denham Vaughan and Edmond ${ }^{27}$ note that to be healing and restorative, silence demands authentic presence and a willingness to remain open to what emerges.

\section{Focus three. The practice of silence}

Thirteen papers refer to silence as a practice: this may be the explicit introduction of a meditative process during therapy, ${ }^{26,33}$ or the more implicit use of mindfulness techniques; ${ }^{6}$ it may be a recommendation to adopt a personal spiritual practice ${ }^{24,34}$ or simply to still oneself sufficiently to be fully present. ${ }^{29}$ The distinction between use and practice is described by Back et $\mathrm{al}^{6}$ as 'the quality of mind the clinician contributes to the encounter' (p. 1113); compassionate silence grounded in contemplative practice 'requires active intentional mental processes - it is the opposite of passive, receptive activity' (p. 1114).

Similarly Denham-Vaughan and Edmond ${ }^{27}$ describe silent presence as being fully in the here-and-now, being present to embodied self and Tornøe et al. ${ }^{22}$ describe the deeply personal and relational practice of being there for the other person in the encounter. Barber ${ }^{19}$ notes that shared silence leads to deeper connection between the individuals 
involved; others refer to a connection with something more that depending on personal spirituality, may be the presence of God, ${ }^{32}$ the recognition of a divine spark ${ }^{33}$ or, for Denham-Vaughan and Edmond, ${ }^{27}$ a 'profound inter-connectedness with all that is' (p.5).

Chaplain, Capretto ${ }^{30}$ suggests that silence has the potential to provide a transitional medium; caregiver and cared-for meet as human beings in a liminal space. In nursing, Tornøe et al. ${ }^{23}$ and Savett ${ }^{34}$ suggest that the tool is not silence but the caregiver him or herself, used to nurture a mutual sense of understanding and care.

Several papers describe being with another in silence as an act of nonabandonment, ${ }^{30,32,34,35}$ demonstrating willingness to remain in an uncomfortable place. ${ }^{6,25,27,30,31}$ Where speech or interruption might indicate rejection, ${ }^{31}$ silent presence is found to be enabling ${ }^{25}$ allowing space and time for the other person in the encounter. ${ }^{26,30,32}$ Capretto $^{30}$ suggests that silence facilitates processing work that cannot be achieved in isolation.

Being silent with another who is suffering is recognised as challenging. ${ }^{6,22,24,25,27,30}$ Bravesmith noted difficulty in maintaining attention ${ }^{28}$; Sabbadini ${ }^{23}$ highlights the temptation to interject with words. Other authors described silences as uncomfortable, or distressing as the pain of another person is shared; $6,23,25,29$ but also 
as privileged ${ }^{24}$ and rewarding. ${ }^{22,24}$ Torn $\varnothing$ e et al. ${ }^{22}$ find that embracing silence demanded a mental shift from 'doing something for the patient' to focusing on 'being with the patient' (p.6); this demands personal courage.

This synthesis has led to a line-of-argument to inform understanding of silence, as care, in palliative settings.

\section{Discussion}

Main findings: The interpreted line-of-argument concludes that silence supports therapeutic communication especially in spiritual and existential domains of care where words may fail. This may be particularly relevant at the end of life when speech is compromised and spiritual care is integral to care. Due to the nuanced nature of silence generalisations cannot be made about use or practice but the experience explored in this article may find resonance with a wider international audience.

The relationship of silence and speech is conceptualised as a partnership ${ }^{23,28}$ in which silence facilitates listening, ${ }^{34}$ bearing witness, ${ }^{29}$ empathy ${ }^{30}$ and consoling presence..$^{22}$ These are qualities recognised as important in palliative spiritual care..$^{36,37}$ In addition, silence enables deep communication beyond the limits of language; this can foster healing. ${ }^{6}$ There is an inference that, for silence to be effective as care, the quality of a caregiver's silence should be intentional ${ }^{34}$, a conscious disposition. 
Silence is multifunctional; ${ }^{21,23}$ it is used for multiple intentions and evokes multiple perceptions. It has the potential to enhance the therapeutic relationship ${ }^{20}$ being empowering ${ }^{24}$ and transformative..$^{25}$ In this study, use of silence is discussed predominantly from the psychotherapeutic perspective. Articles which report experience in palliative care focus more on a practice of silence as presence, characterised as a movement from 'doing' to 'being', in order to build a relationship where silence itself can offer care. Several authors, across disciplines, note the challenges of this in a western culture which seems to prioritise speech.

In all settings, silence as an element of care is presented as complex and demanding. Silence, as presence, is a difficult skill to master; ${ }^{24,25}$ it takes experience ${ }^{19,20,21,23}$ and practise..$^{6,24,34,35}$ It involves letting go of ego ${ }^{26}$ and a shift of focus from self to other that is integral to compassionate care ${ }^{6}$ Authors highlight the need for education and opportunities for practice. However the shared perception, in all the selected papers, is that silence is of value. Across disciplines authors use words such as useful and helpful, ${ }^{19,21}$ beneficial, ${ }^{6,24,29}$ and empowering. ${ }^{25}$ Several papers suggest that silence appears to effect transformation,,$^{30,31,33,35}$ fostering a connection that goes beyond the power of words $24,26,30,32$ and with the potential to relieve spiritual and existential suffering. ${ }^{22}$ 
Strengths and weaknesses: The strength of this review is that it contributes a novel interpretation of silence as an element of care from an international and interdisciplinary perspective albeit only in western cultural settings. Thus, a limitation is that no experience from an eastern cultural perspective is discussed. No other such review has been found. Whilst lack of empirical evidence may be deemed a weakness it highlights the need for research. In reports of primary experience, authors demonstrate a prior interest in silence, and some write as advocates of the phenomenon.

What this study adds: The reviews draws together experience from cross-disciplinary sources to enhance understanding of silence as an element of care in palliative care; the findings of empirical research in psychotherapy ${ }^{19,20,21}$ support and build upon existing palliative care knowledge. ${ }^{6,22,25,30} \mathrm{~A}$ line of argument synthesis offers an interpretation of the material that is relevant to palliative care; it seeks, not to provide answers, but to stimulate further interpretations and discussion. ${ }^{14}$ The review supports the case for further research, within palliative care in order to deepen understanding of qualities of silence as an element of care. Findings highlight the need for training in the use of silence and opportunities to practice silence, for professional caregivers. 


\section{Conclusion}

This review presents a synthesis of published papers which report professional caregivers' experience of silence as an element of care in clinical settings including end-of-life care, nursing, chaplaincy, psychoanalysis, psychotherapy and counselling. The interpreted line of argument supports existing understanding in palliative care that silence is an important element of communication and compassionate care. Silence is noted as particularly relevant in the spiritual and existential dimensions of care where words may fail. Silence can prove challenging for caregivers; training and practice are advocated. A deeper understanding of the qualities of silence as an element of care may offer benefits for clinical practice and patient care.

\section{Funding}

This research received no specific grant from any funding agency in the public, commercial, or not-for-profit sectors.

\section{Conflict of interest}

The authors declare that there is no conflict of interest. 


\section{References}

1. Twycross, R. Introducing palliative care $4^{\text {th }}$ ed. Oxford: Radcliffe Medical Press, 2003.

2. Silverman, J., Kurtz, S., Draper, J. Skills for communicating with patients $2^{\text {nd }}$ ed. Oxford: Radcliffe, 2005.

3. Bradley, C. Core competencies in palliative care for surgeons: interpersonal and communication skills Am J Hosp Palliat Care, 2008; 24: 6499-6507

4. Firth-Cozens J, Cornwell J. Enabling compassionate care in acute hospital settings London: The King's Fund. 2009 Apr.

5. Puchalski CM. Spirituality and the care of patients at the end-of-life: an essential component of care. OMEGA-Journal of death and dying. 2008 Feb;56(1):33-46.

6. Back A, Bauer-Wu S, Rushton C et al. Compassionate silence in the patient-clinician encounter: A contemplative approach J Palliat Med 2009; 12(12): 1113-1117.

7. Saville-Troike, M. The place of silence in an integrated theory of communication In: Tannen,

D, Saville-Troike, M Eds. Perspectives on silence Norwood: Ablex 1995. pp. 3-18

8. Sharpley C, Munro D, Elly M. Silence and rapport during initial interviews Counselling Psychology Quarterly 2005; Vol 18(2): 149-159.

9. Lane, J. The spirit of silence: making space for creativity Totnes: Green, 2006.

10. Kabat-Zinn, J. Wherever you go, there you are: mindfulness meditation for everyday life London: Piatikus, 1994.

11. Twycross, R. Palliative care, the joy of death Lancet 1997; 350 (suppl III): 20

12. NHS Scotland Spiritual care and chaplaincy Edinburgh: The Scottish Government, 2009.

13. Rumbold, B. Pastoral care Australia: The Pastoral Care Council of the ACT Available at http://www.pastoralcareact.org/pastoral.html (Accessed 06/06/2017)

14. Noblit G, Hare R. Meta-ethnography: Synthesising qualitative studies California: Sage, 1988.

15. Popay J, Roberts H, Sowden A. et al. Narrative synthesis: a methodological review. Developing methods for the narrative synthesis of qualitative and quantitative data in 
systematic reviews of effects.

http://www.lancs.ac.uk/shm/research/nssr/research/dissemination/publications.php (2006, accessed 29 April 2015).

16. Hawker S, Payne S, Kerr C et al Appraising the evidence: reviewing disparate data systematically Qual Health Res. 2002 Nov;12(9):1284-99.

17. Pope C, Mays N, Popay J. Synthesising Qualitative and Quantitative Health Evidence A Guide to Methods Maidenhead, UK: Open University Press, 2007.

18. Moher D, Liberati A, Tetzlaff J, et al. The PRISMA Group. Preferred reporting items for systematic reviews and metaanalyses: the PRISMA statement. PLoS Med 2009; 6(7): e1000097. https://doi.org/10.1371/journal.pmed.1000097

19. Barber T. Newly qualified counsellors' experience of silence within the therapeutic setting. MA dissertation, Roehampton University, UK, 2009.

www.contemporarycollege.com/images/uploaded/MA_dissertation_publication.pdf (accessed 3 June 2015).

20. Hill C, Thompson B, Ladany N. Therapist use of silence in therapy: a survey Journal of Clinical Psychology 2003; 59(4): 513-524.

21. Ladany N, Hill C, Thompson B et al. Therapists perspectives on using silence in therapy: a qualitative study Counselling and Psychotherapy Research 2004; 4, 1: 80-89.

22. Tornøe K, Danbolt L, Kvigne K et al. The power of consoling presence - hospice nurses' lived experience with spiritual and existential care for the dying BMC Nursing 2014, 13:25: 1-8.

23. Sabbadini A. Listening to silence BJP 2004; 21(2): 229-240.

24. King K. Using therapeutic silence in home healthcare nursing Home Healthcare Nurse 1995; 13(1): 65-68.

25. Himelstein B, Jackson N, Pegram L. The power of silence J Clin Oncol 2003; 21, 9S: 41s.

26. Hill M. The silence of the body J Relig Health 2004; 43, 1: 29-43.

27. Denham-Vaughan J, Edmond V. The value of silence Gestalt Journal of Australia and New Zealand, 2010; Vol 6, No 2: 5-19. 
28. Bravesmith A. Silence lends integrity to speech: Transcending the opposites of speech and silence in the analytic dialogue British Journal of Psychotherapy 2012; 28(1): 21-34.

29. Bunkers S. Silence: a double edged sword Nursing Science Quarterly 2013; 26(1): 7-11.

30. Capretto P. Empathy and silence in pastoral care for traumatic grief and loss J Relig Health 2015; 54: 339-357.

31. Harris A. The experience of silence: a client case study Counselling Psychology Review 2004; 19, 1: 5-11.

32. Moriichi S. Re-discovery of silence in pastoral care The Journal of Pastoral Care and Counselling 2009; 63 (1-2): 1-6.

33. Rajski P. Finding God in the silence: contemplative prayer and therapy Journal of Religion and Health 2003; 42, 3: 181-190.

34. Savett L. The sounds of silence: exploring lessons about silence, listening, and presence Creative Nursing 2011; 17, 4: 168-173.

35. Wilmer H. Silence: something we rarely hear, which does not exist Journal of the American Academy of Psychoanalysis 1995; 23(4): 723-730.

36. Puchalski, C.M. Spirituality and end-of-life care: a time for listening and caring Journal of Palliative Medicine 2002; 5(2), 289-294.

37. Edwards, A., Pang, N., Shiu, V., Chan, C. The understanding of spirituality and the potential role of spiritual care in end-of-life and palliative care: a meta-study of qualitative research. Palliative Medicine 2010; 24(8), 753-770. 